\title{
Historical Development of the Zakat System Implications for Social Work Practice
}

\author{
$\overline{\text { Zulkipli Lessy }}$
}

\begin{abstract}
Zakat, infaq, shadaqa, waqf, dan qurban adalah sumber kesejahteraan sosial bagi delapan golongan mustahiq. Studi sejarah perkembangan zakat menguak sistem dan praktek zakat yang berkembang mengikuti dinamika masyarakat. Terdapat hubungan yang signifikan antara zakat dan konsep kesejahteraan sosial Islam sebab zakat digunakan untuk mendukung subsidi kesehatan, pendidikan, dan ekonomi para mustahiq. Konsep-konsep derma wajib (obligatory giving) dan tidak wajib (voluntary giving) dalam Islam, keberhasilan LAZIS dalam melayani mustahiq serta perannya dalam memberdayakan kaum miskin akan dibahas dalam beberapa model program, termasuk juga implikasi kajian ini bagi praktek pekerjaan sosial di Indonesia.
\end{abstract}

Key words: zakat, obligatory and voluntary giving, social work.

\section{Introduction}

Zakat is a system of obligatory and voluntary alms-giving practiced by followers of the Islamic religion. Because Muslims constitute $21 \%$ of the 6.93 billion world population, the charitable potential for zakat is considerable. Four Asian countries are home to the four largest Muslim populations, and thereby account for $47 \%$ of all Muslims. Bangladesh has $10 \%$, India has $11 \%$, Pakistan has $12 \%$, and Indonesia tops the list with $14 \%$ of Islam's 1.46 billion adherents worldwide. The 212 million Muslims in Indonesia are 86\% of their country's 246 million inhabitants, and hence zakat is a tradition familiar to nearly all Indonesians. (CIA World Factbook, 2011)

As one of the five pillars of Islam, zakat has long been fundamental to Islamic social welfare, yet its practice declined after the 18th century. Zakat has revived during the last fifty years while Muslim governments in Pakistan, Malaysia, Saudi Arabia, or Kuwait put it more firmly into their official social welfare structures. In 1968 Indonesia's non-Islamic government established its Badan Amil Zakat (BAZ). Even so, zakat is implemented in Indonesia via both public and private methods.

The Undang-Undang Dasar 1945 governs Indonesia's thirty-three provinces, its two special regions (Aceh and Yogyakarta) and its capital city district (Jakarta). The UUD 1945 initially and over time has been adjusted to reflect indigenous concepts. Because the government is not based in Islamic shari'a law, the Indonesian taxation system has developed without clearly embedding zakat. Aspects of the traditional charitable system are entwined in, yet also obscured by a mix of governmental policy and agencies, philanthropic institutions, and social work initiatives. Indonesians lack clarity on how to fulfill their zakat obligations, and the national zakat potential is not attained.

The practice of zakat has varied over time and place, usually being implemented by means of state structures. Strong Islamic governments provide protection and guidance for zakat, which functions as a tax supporting the states' income and expenditures. In non- 
Islamic states, the practice of zakat is implemented by communities. In such settings, zakat is not explicitly included in the tax system, and thus individuals and social institutions become involved in accumulating and disbursing zakat. After Indonesia implemented decentralization at the start of 2001, the country's regencies and municipalities became the key administrative units responsible for most government services. This research uses secondary sources that are believed to be reliable and have unique advantages because most of them are theoretical based-research.

Zakat, an obligatory form of giving, and other forms of voluntary giving are the foundation of Islamic social welfare. In the last fifty years, revivalists advised Muslims to effectively use zakat to address poverty. Zakat practices developed mainly in early and medieval periods of Islam, but after the 18th century, these practices declined. These practices re-evolved because of a strong moral consciousness that has risen among Muslims due to the needs of Muslims becoming more increasingly complex. In order to remediate these needs, some Muslim governments employed a zakat system included in their social welfare schemes. For example, in the 1960s, Pakistani President Zia Ul-Haq established the Central Zakat Councils. Some Islamic governments adopted this system into their national tax structure. In 1968, Indonesian President Suharto established BAZ, and in the 1990s, Indonesian non-governmental organizations (NGOs) founded Lembaga Amil Zakat, Infaq, dan Shadaqa (LAZIS).

More recently, zakat has become an academic concern among Indonesian social workers and philanthropists because they believe that zakat has the potential to eliminate poverty. In 1997, these activists established the National Zakat Forum network for zakat programs. In 2010, with international zakat activists, they co-founded a World Zakat Forum to build a global network of zakat management. Inspired by religious activities in the church, social workers in the West have enacted aid provisions for the poor. This inspiration might encourage Indonesian social workers to empower the poor through zakat funds. Since the 20th century, social work has widened its scope to accommodate varied sectors of the population; however, social work among Indonesian academics is a new field of study. But the term social work, connoting help among fellow humans, is not a new movement among Muslims because the concepts of takaful (solidarity) and bayt al-maal (house of treasury) have existed in Muslim societies for centuries.

\section{Concepts of Islamic Obligatory Giving}

\section{Zakat}

Zakat is the religiously obligatory giving that stands as the third of five pillars of Islam. The five pillars are the requirements established in Muslim culture and law as the bases for any Muslim to be considered an authentically faithful believer. The word zakat means growth, and by extension, growth in purity of the soul through honest actions and dealings. The word zakat occurs in the Qur'an: “...the believers, men and women, are protecting friends one of another; they enjoin the right and forbid the wrong; they establish worship and pay zakat..." (at-Tawba 71). Zakat designates the contribution that every solvent Muslim must make for societal assistance and subsidize social establishments and works of public welfare for benefit and progress in the growth of the community. (Farishta G. de Zayas, 2007) 
Zakat was first instituted in the 7th century. At that time, the characteristics of the obligation were specific and include details of donations and amount be paid. Practically, the amount of zakat varied according to each Muslim's impulses to philanthropy and their altruism. In the 8th century, Muslim scholars interpreted zakat as obliged in greater specificity in the Qur'an. The details of this responsibility are explained in at-Tawba 60, which specifies the eight groups entitled to zakat. (Zulkipli Lessy, 2009 : 155-175)

\section{Zakat Fitr}

Zakat has two forms, the simplest of which is zakat fitr. This personal charitable almsgiving is an annual requirement for each solvent Muslim at the end of the fasting month of Ramadan. (Muhammad Akhyar Adnan and Nur Barizah, 2009: 32-45). Zakat fitr represents one day's fast. Each individual donor must pay annual zakat fitr in an amount equal to the donor's typical one-day expenditure for food. The amount of zakat fitr should equal the worth of $2.5 \mathrm{~kg}$ of the indigenous local staple. (Sahih Al-Bukhari, 1997). Modern Muslims can pay zakat in cash, rather than having to provide the foodstuffs themselves. (Hans Visser, 2009).

Money and goods are used as the measurement for paying zakat, such as daily consumption for zakat fitr and productive wealth for zakat maal. Zakat fitr payment differs according to place and time. General payment is cash equivalent to $2.5 \mathrm{~kg}$ of the local staple food, such as rice, wheat, lentils, or corn. (Ibid). In 2010, some Muslim Indonesians paid their zakat fitr as Rp 20,000; however, there is no exact rate Muslim Indonesians paid this form of zakat, and it depends on their economic capacity. In the same year, Muslims in the United States paid $\$ 8$ according to economic standards in this wealthier country. (Islamic Society of North America, 2010). Paying the minimum amount means that an individual's welfare is Rp 20,000 or $\$ 8$, with which he or she can eat as well as buy complementary foods. If a Muslim cannot pay zakat fitr because his or her daily consumption is below the nishab, then he or she deserves to receive zakat.

\section{Zakat Maal}

Zakat maal is the second form of religiously obligatory giving for Muslims. The Arabic word maal means wealth. Zakat maal is an alms-tax which is levied on an individual's productive wealth that had been held for at least one lunar year, and it is calculated in the form of a certain percentage levy for each taxable asset. A typical levy is $2.5 \%$ alms-tax on productive assets; $5 \%$ of irrigated crops, and $10 \%$ of non-irrigated crops at harvest. Above specified thresholds, zakat maal is assessed at prescribed rates for each taxable wealth category when individual personal property exceeds certain annual exempt amounts, after allowing for spending on basic needs. (De Zayas,2007). In particular, zakat maal must be calculated on such property as silver, gold, money, cultivated produce, domestic animals, merchandise items, and other items of inherent or useful value. The rates and amounts of zakat maal levies are stipulated by shari'a. Rodney Wilson, 2004 : 195-222)

Wheeler provided the list of items on which zakat maal is determined and about which there is agreement among Muslim jurists: two types of minerals (gold and silver not used for ornamentations), four types of animals (camels, cows, sheep, or goats), two types of grain (wheat and barley), and two types of produce (dates and raisins). (Brannon Wheeler, 2004 : 
89-119). This list is specific, and a number of Muslim jurists insist that zakat is to be given on these items only. There is a disagreement regarding items that are judged by analogy to be included in the requirement of zakat. For instance, because some of these foods are not found in a region with tropical climate, Muslims in this region are allowed by sha'ria to pay zakat in the form of their local staples, such as rice and cassava.

To determine how much zakat should be given, a hadith from the 14th century attempted to assign an exact monetary value to nishab. Muslims are not required to pay zakat if their wealth's value is less than five uqiyas of silver (143.3 grams) or five wasqs of food $(180 \mathrm{~kg})$. (Al-Bukhari) In the present day, Indonesian nishab is also interpreted for ordinary earnings and salaries, and it requires Muslims to pay zakat maal when their annual income exceeds the relevant threshold. However, farmers should not pay zakat when their earnings are less than Rp 2 million or about $653 \mathrm{~kg}$ of rice during each harvest, and office workers should not pay zakat when their net annual income is less than Rp 6.800.000 (\$680). (Faqihuddin Abdul Kodir, 2004: 85-100)

\section{Concepts of Islamic Voluntary Giving}

\section{Infaq}

Infaq is one type of Islamic voluntary giving, typically in monetary form and without using intermediaries. Senturk defined the word infaq as giving wealth for particular needs. Benefits are often given directly from donors to poor individuals, orphans, and people who are in difficult situations due to disaster or poverty. (Omar Faruk Senturk : 2007). Infaq can also be given to institutions with a primary need-directed intent of promoting the wellbeing of individuals, families, and the community. Disbursement of infaq is encouraged to be done by Muslims whenever they receive both regular income, such as monthly salaries, and non-regular income, such as periodic bonuses or one-time gifts. (Muhammad Daud Ali, 1998). Infaq differs from obligatory zakat in that no law regulates an exemption rate above which infaq is supposed to be calculated, nor are there any fixed percentage rates for calculation, and the potential infaq recipients are not defined or categorized in the manner of zakat's eight classifications.

\section{Shadaqa}

Shadaqa is voluntary giving of resources by a Muslim to Muslims or to non-Muslims, and especially to the poor. Unlike the case for zakat, there is no regulated time of year for Muslims to give shadaqa. The faithful can pay these voluntary alms whenever they wish. There is also no regulation on the amount of money which should be donated, so long as it will not impoverish the giver. Shadaqa also includes giving services that are meaningful for the recipients. (Abdool Aziz Shaik, 1981:3-67). For example, someone who teaches children without seeking to be paid is thereby providing shadaqa. Shadaqa has a wide meaning, and the Qur'an uses the word for any kind of voluntary contribution. (Senturk, 2007). Because several verses of the Qur'an, such as at-Tawba 90, do employ the terms shadaqa and zakat interchangeably, there is overlap with the linguistics of obligatory giving, which is more accurately designated as zakat. 
Waqf is charitable endowment, and the word itself translates as "withholding." The present and/or future benefits from income on such an endowment are bestowed for a purpose. (Ahmad Dallal, 2004 : 13-43). No third party can claim the specific property that constitutes the principal, which generally is a certain amount of money, land, or means of production endowed to a recipient. Since waqf is a form of individual, family, or community contribution, it can be owned and directed by families, communities, or institutions, but not by an individual. Arjomand noted that this tradition is not rooted in the Qur'an, but rather was developed by Islamic juries in the 8th century. (Said Amir Arjomand, 1989 : 165178). The Caliph Umar ibn al-Khattab (r. 634-644) first endowed vacant land in Khaybar as community gardens, which were used for the community well-being as the first waqf in Islamic history. (Farid Wadjdy and Mursyid, 2007). Waqf funds of the 15th century in Central Asia supported development of mosques, madrasas, and colleges to perpetuate cultural tradition. The staff and users of these institutions received salaries and stipends from waqf revenue. (Robert D. McChesney, 1995). In the late medieval centuries, the Ottoman Empire developed waqf systems via individual donations, such as monies from salaries, as well as via charitable investments by the imperial family and its most prominent officials. (Gregory C. Kozlowski, 2008) In Indonesia, Muslims typically endow waqf funds in the form of land on which to build mosques, schools, cemeteries, and community meeting buildings. (Wadjdy and Mursyid, 2007)

\section{Qurban}

Ali reported that qurban is a specific form of shadaqa in which meat is given primarily to the poor after slaughtering. Qurban is given yearly in the month of hajj (pilgrimage). The meats of qurban are usually goat and cow. Qurban originally symbolized the sacrifice of a Muslim through his or her donation of some portion of his or her wealth for the social welfare of the poor. The term 'qurban' is rooted in the experience of Abraham, who was dered by God to sacrifice his son Ishmael as proof of his love for God. Muslims are encouraged to slaughter lawfully edible animals at least once in their lives. (Ali, 1998)

\section{Issues on Zakat}

Zakat was instituted in the 7th century. At that time, the characteristics of the obligation were specific and include details of donations and amount be paid. Practically, the amount of zakat varied according to each Muslim's impulses to philanthropy and their altruism. In the 8th century, Muslim scholars interpreted zakat as obliged in greater specificity in the Qur'an. (Yusuf Al-Qardawi,1999). The details of this responsibility are explained in at-Tawba 60, which specifies the eight groups entitled to zakat. Many Indonesian Muslims think that zakat recipients are only Muslims as specified in the Qur`an. However, a Jordanian Muslim scholar, al-Khayyat suggested that zakat can be given to non-Muslims. He interpreted word 'al-fuqara' (the poor) in at-Tawba 60 must mean in Arabic 'all the [categories of the] poor', and therefore it must include non-Muslims. (Jonathan Benthall, 1999: 27-42)

Such interpretation is possible because the Qur'an only gives broad lines about zakat recipients but does not specify that Muslims are the only recipients. (ibid). However, Muslim scholars, such as Qardhawi and al-Zuhaili, believe that zakat should not be given 
to non-Muslims. Besides barring non-Muslims as recipients, these scholars also stated that zakat cannot be distributed in any of the following ways: a) to build public facilities, such as bridges and mosques (unless the mosques are for muallaf who live in non-Muslim countries); b) for Muslims who are able to work and fulfill their own basic needs; c) for non-Muslims; d) for the child or parent or wife of zakat giver; e) for members of the Prophet Muhammad's tribes.

This author does not agree with the first category because public facilities are important. Even public facilities are under the government's responsibility; when the government is unable to build these facilities, then society has the responsibility to build them using zakat funds. This writer also does not agree with the fourth category because Muslims and other faith adherents live in one community. Therefore, it is not wise to exclude those who have not converted to Islam to receive zakat.

Al-Khayyat's perception is that zakat can be given to poor non-Muslims because the Qur'an does not explain whether the word fuqara (the poor) refers to Muslims or nonMuslims. This unclear word can be interpreted as non-Muslim poor who can receive zakat because the Prophet Muhammad said: "I swear by whom my soul is in His hand, you will not enter paradise until you believe, and you will not believe until you love each other." (Sayyid Sabiq, 1992). Loving each other means also loving non-Muslims. So when there are non-Muslim poor, Muslims should help them with zakat funds. Islamic teachings place stress on the public good rather than on a particular entity's interests.

According to Mas'udi, zakat is the only deed in Islam that is concerned with equal access to material resources. The basic concept of zakat as a redistribution mechanism of wealth is that it shall distribute $2.5 \%$ of possessions from the haves--those who have more than they need in their daily lives--to the have-nots. (Masdar F. Mas'udi, 1995 : 30-37) Islam maintains that the haves should contribute zakat voluntarily because the objective of zakat is to build society's cohesiveness. But, because humans suffer from the passion of love of possessions, the presence of zakat institutions is considered necessary.

\section{Zakat Institutions}

After Indonesia proclaimed its independence from the Dutch in 1945, the practice of zakat changed several times. In President Soekarno's government (1945-1966), zakat was at first maintained largely as it had been practiced in the Dutch colonial government in the late 19th to the early 20th centuries. During this time, Muslims were allowed to fulfill their zakat obligation without the Dutch government's intervention, and Muslims did not have official zakat institutions as they have now. In the 1950s, Muslims unsuccessfully tried to persuade President Soekarno to establish Islamic law or shari'a, and this resulted in a political agreement in what is called the Jakarta Charter--which required the omission from the constitution of the seven words translated into belief in the one supreme God with the obligation to live according to shari'a for Muslims." ( B. J. Boland, 1982) Since Muslims themselves were able to administer zakat through mosques and other traditional systems, the government could support regulations without imposing its values on Muslims. (Amelia Fauzia, 2008) 
The shift of state administration from President Sukarno to President Suharto in 1966 did not change even this zakat policy. However, in President Suharto's government from 1966 to 1968, some Muslims demanded the state administer zakat. The belief that the Jakarta Charter could be used as support for Indonesian religious life led these Muslims to call for the administration of zakat by the government. In 1967 the Minister of Religious Affairs drafted a zakat bill in the legislature, but the legislature did not discuss the bill ${ }^{1}$ (Boland, 2006: 683-701). This eventually led to the creation of zakat institutional models know as BAZIS during Suharto's era. On one hand, it is a result of some Muslims' demand for zakat administration, and on the other hand, Suharto saw potentials in zakat to create social welfare by establishing his foundation. LAZIS establishment after Suharto era was based on the change in political situations.

The interpretations of the Qur'an, at-Tawba 60, have developed over the years, and these interpretations continue to affect situations in society. Al-Qardawi inspired many Muslims to think about philanthropic concepts with his work, Fiqh Zakat. (Al-Qardawi, 1999). This work cements the foundation of modern outlooks of Islamic philanthropy. AlQardawi determined that zakat has three dimensions: social, economic, and religious. His ideas stimulated the rapid growth of LAZIS which professionally manage zakat funds.

Zakat trends have changed over time, and no single pattern of zakat development has emerged. From the 7 th century to the 8 th, the state imposed its rules on this practice in order to maintain its protection, regulation, and control of the mechanism. Because the Muslim community was newly emerging, they needed a government supported by taxes or zakat funds. During those centuries, zakat was adapted to ensure the economic growth of the state. Shortly after the Prophet Muhammad passed away, some of his companions were reluctant to pay zakat, but the Caliph Abu Bakr responded to their reluctance with a military action. (Timur Kuran, 2003: 275-293) In addition, the caliph agents also collected taxes on horses. These events showed how important zakat is and that it should be paid by solvent Muslims.

As of the Abbasid Caliphates, zakat was still administered by the state. During this time, zakat had the same characteristics as zakat in early Islam. One exception in Muslim history can be seen when some of the certain Sultans of Mamluk, Egypt tried to implement harsh penalties on those who avoided paying zakat. This retribution, to some extent, was tolerated because the state was expected to act properly whenever citizens ignored their obligation as zakat payers. From the 15th century onwards, when the state encouraged voluntary giving by its citizens, the givers could donate more than required. This was an effective way to raise funds from sources other than zakat because the percentage of the zakat requirement is limited in a predetermined way. This expansion of the zakat system was nurtured by the Ottoman Empire which developed the waqf system that supported Muslim philanthropy (Amy Singer, 2008). The waqf funds were used for such functions as education, community care systems, and public kitchens. Fauziadrew similarities between the practices of philanthropic giving in the Ottoman Empire and Indonesia's archipelago where some Islamic kingdoms echoed the Ottomans' zakat practice. Over the next hundred

1 Boland, The Struggle of Islam...; Arskal Salim, "The Influential Legacy of Dutch Islamic Policy on the Formation of Zakat (Alms-giving) Law in Modern Indonesia," Pacific Rim Law and Policy Journal 15, no. 3 (2006): 683-701. 
years, the presence of the Dutch in Indonesia partly degraded the collection and distribution of zakat by the kingdoms because the Dutch thought that this practice could be used to fund a revolt against them. The trend during this period was for zakat to be collected by traditional institutions. Although the collection was also often done by the local governments, the roles of indigenous institutions such as mosques were significant to respond to the needs of the communities. (Fauzia, 2008)

This trend, however, changed during the end of the Dutch era in the 19th century. In this later era, the Dutch gave permission for Muslims to manage their own zakat system. The Dutch were then more neutral and flexible in their response to Muslim attitudes of self-collection of zakat. (Arskal Salim, 2008b) Starting with President Sukarno from the independence era of 1945 to the 1960s, the trend reverted back to traditional channels with mosques collecting funds and individuals giving directly to the needy. However, there were still some socio-religious organizations, such as Muhammadiyah, had many reasons to collect zakat from the community to support educational goals, orphanages, and other socio-cultural programs.

Despite the trend toward traditional channels, zakat under President Suharto underwent politicization by the state. Although Suharto played a major role in the establishment of the BAZIS - similar to what was established in Pakistan in the 1960 s by President Zia U1Haq (Grace Clark, 2001: 47-75) — the establishment of hundreds of mosques by Suharto's foundation cannot be said to have helped the development of civil society in Indonesia. People still question the transparency and accountability of Suharto's foundation. The era of reformation after the collapse of Suharto's government in 1998 marked new growth of zakat institutions through new zakat legislation.

The trends of zakat administration have varied over time, and such evidence suggests further research on the topic is needed. During Suharto's government, zakat collection and distribution were supported by the bureaucracy. Toward the end of his presidency, some NGOs had started to collect zakat. This action was the beginning of a move from individual methods to institutional methods. Some researchers believe that the shift from giving to individuals to giving to institutions will result in more effectively reducing poverty. The Public Interest Research Advocacy Center estimated that the national zakat potential in Indonesia would be 14 trillion rupiah. (Robert Dobias, 2002). The combination of zakat with other voluntary gifts has the potential to generate 19 trillion rupiah in a year that can be used to help the needy. (Chaedar S. Bamualim, 2009 : 75-88)

\section{BAZIS Model}

Founded by President Suharto in 1968, Badan Amil Zakat (BAZ) is the governmentsponsored zakat bureau. The structure of this bureau exists within the governmental offices. In the provincial level, this bureau is chaired by the governor or the head of Provincial Religious Affairs office. Suharto's administration during the late 1960s had ignored some Muslims' political ideals, and in order to conciliate Suharto's relationship with them, he established BAZ, first national zakat institution in modern Indonesian history. In 1969, Suharto instructed his governors to establish zakat institutions and functionaries at provincial 
levels. As a result, Jakarta Province was first to establish BAZ. (Taufik Abdullah, 1991 :50-84) Shortly thereafter, almost all provinces had BAZ regional offices under Suharto's military governors. The administration put all of the zakat funds into Suharto's account rather than into the public account of the Ministry of Religious Affairs. Suharto is believed to have been able to appropriate zakat funds because the BAZ was not transparent about how much money the institution collected and distributed and because no structures existed for auditing this foundation. (Arskal Salim, 2008a).

BAZ's patronage by President Suharto lasted only a few years. In 1974 he assumed the role of national zakat collector. In fiscal year 1969-1970, he delivered only a single budget report in the amount of Rp 39.5 million $(\$ 2,473)$. Considering the growth of the Indonesian Muslim population, Suharto's figure was disproportionately low. In response to the paucity of the zakat fund, Suharto stepped down from the collector position in 1982. Suharto's resignation belied his true intent behind a brief stint as national zakat collector, which had been to secretly impede the Ministry of Religious Affairs' application of the Jakarta Charter for creation of a national shari'a-based system for zakat. Once Suharto's thwarting of the Jakarta Charter application had been accomplished, there was no need for him to continue collecting zakat. (Salim, 2008a)

In 1982 after his resignation from the collector position, Suharto established the Pancasila Muslim Charitable Service Foundation, which aimed to develop the capacity of Muslims culturally. This foundation levied amounts for the supposedly voluntary almsgiving such as shadaqa, but not for obligatory zakat, by deducting a monthly contribution of between Rp 50 and Rp 1,000 from the salaries of all Muslim civil servants. This foundation built "394 mosques at a cost of Rp 39.6 billion." (Michael Vatikiotis, 1990: 62-63) Since shadaqa and zakat are occasionally used as interchangeable concepts in the Qur'an, Suharto's action could be seen as founding a new zakat establishment with a different purpose from BAZ. Acting as national zakat collector in the late 1960s to early 1970 s, Suharto did not levy zakat in the same way that he levied alms-giving through his new foundation. Although Suharto was able to impose shadaqa on government employees, it would have been more challenging for him to forcibly levy the obligatory religious requirements, such as zakat, in his non-shari'a system. (Salim, 2008b)

BAZ, established under Suharto's new administration in 1968, drew zakat only, but in the middle of the 1980s, it also began including voluntary giving other than zakat. As a result, its name changed to become BAZIS, which stands for Badan Amil Zakat Infaq and Shadaqa. In the 1970s, such provinces, namely East and South Kalimantan, West and South Sumatra, West Java, and Lampung established their BAZIS, and followed by the North and South Sulawesi that established their BAZIS in the 1980s. In the same decade, oil companies, such as Badak LNG and Pertamina, established their BAZIS as corporate social responsibility. (Abdullah, 1991)

\section{LAZIS Models}

\section{Dompet Dhuafa}

The famine in Gunung Kidul Regency in 1993 motivated newspaper employees of Republika to establish Dompet Dhuafa (DD) Foundation. They also established the 
Republika Brotherhood Association to collect funds. This association deducted $2.5 \%$ of its members' monthly incomes as their zakat obligation. In that year, after the fund was donated to the entitled, the community needed much more. As a result, DD involved Republika readers by dedicating a small space on the front page to appeal for donations. In the first few days, DD collected Rp 425,000. By the end of 1993, DD had collected Rp 90 million, including the monthly zakat fund from employees. (Hamid Abidin, 2004)

DD has three major programs: economic, agricultural, and human resource development. The first DD program, economic development, encompasses two main areas, namely micro-finance loans and small-scale enterprise development. In order to accomplish the economic development program, DD has built a network, which includes more than 59 organizations nationwide, to establish the Bayt al-Maal wat Tamwil (BMT); and in joint with the People Credit Shari'a Bank, this network lends money to zakat recipients who want to start businesses. The second DD program, agricultural development, provides agricultural producers with reasonable prices to ensure production continuity and price stability. DD works with partner organizations to provide seed capital and revolving funds. The third DD program, human resources development, focuses on youth education by granting scholarships and sponsoring internship programs. By 2000, more than 300 students received DD-developed scholarships and internships worth Rp 1 billion. In addition, DD finds foster families to help unfortunate children continue their education. DD has also built a network with prospective donors who can send monies to DD through either BMT or other financial institutions to support these needy children. (Dobias, 2010)

\section{Al-Falah}

Established in 1993, and as of 2002, the Al-Falah (AF) Foundation has built a monthly fund of Rp 300 million mainly from infaq funds and based on almost 100,000 donors in East Java Province. AF uses zakat, infaq, and shadaqa as the major sources for its two empowerment programs: Pena Bangsa and Sahabat Asuh. The Pena Bangsa program helps students who have had to drop out of school due to a lack of financial support. AF scholarship amounts depend on the level of education. Monthly support ranges from Rp 20,000 for elementary students to Rp 35,000 for higher-level high school students. To increase its funds for the Pena Bangsa program, AF regularly advertises in local magazines and newspapers. The similar AF program, Sahabat Asuh, encourages children of rich families to donate money to help needy children who are in foster situations. This program aims to enhance societal involvement by the children in the rich families and to provide financial resources for the education of poor children. As of 2003, Sahabat Asuh had at least 70 donors providing about $\mathrm{Rp} 7$ million monthly. These programs built networks with prospective donors who can send monies through the bank to support unfortunate children. (Al-Falah Foundation, accessed September 2, 2010)

\section{Pos Keadilan Peduli Ummat}

The Pos Keadilan Peduli Ummat (PKPU) Foundation was established in 1999. With 14 branches across Indonesia, PKPU's programs support education, health, disaster management, and economic status. The education program provides scholarships for 
children from low-income families and aims to equip children with practical skills through learning experiences. PKPU also provides a mobile library primarily stocked with children's books and magazines. This asset is made temporarily available to a community when a natural disaster has affected its children. In further response to natural disasters, PKPU temporarily provides community-based disaster risk management. The economic program of PKPU lends money to farmers, artisans, retailers, and fishermen who lack resources to start businesses. (ibid)

\section{Rumah Zakat}

Founded in 1998 and as of 2009, Rumah Zakat (RZ) had collected Rp 107.3 billion (\$10.73 million) from 54,000 donors. ( Zulkipli Lessy, 2011) With these funds, it has developed programs to address economic needs of impoverished communities and health care for the poor. Economic programs provide non-profit micro-credit and loans that enable poor households to start businesses and change their status from zakat recipients to zakat donors. Health care treats primarily family-based situations, such as free ambulances and free medical clinics. The RZ's partner hospitals provide Rp 500,000 (\$50) toward medical care for the poor who cannot afford hospital fees, while the bulk of the fees are paid by RZ. Free medical clinic services include: general check-up, immunization, family planning consultation, nutrition counseling, prenatal care, circumcision for young boys, and tumor and cataract operations. RZ also dispatches health care services, including medicine, food, clothes, and tents, for humanitarian aid to victims in disasters and communal conflict zones. (Profil RZI, 2009)

\section{Zakat Policies in the Post-Suharto Era}

Indonesia is not a shari' $a$ law state but has accommodated social needs by facilitating LAZIS institutions to collect and distribute zakat as it previously facilitated its BAZIS, which are semi-autonomous zakat collecting boards established by President Soeharto in 1968 at the federal and provincial levels. Although zakat is considered an obligatory religious donation, it is regulated by civic rules, known as shari' $a$ by-laws. The state considers zakat the obligatory religious donation, as it is required by Islam, but does not impose sanctions against Muslim citizens over their failure to pay zakat. Instead, the state has facilitated the payment of zakat either through BAZIS boards or LAZIS institutions which were mandated by Act No. 17 (2000). Previously, President Habibie (1998-2000) issued the first Zakat Act, No. 38 (1999), which stated that solvent Muslims and corporate bodies should pay zakat maal to the poor or charity foundations. In response to these Acts, community organizations have established LAZIS to facilitate zakat payers to claim a tax deduction.

According to the Tax Director General, zakat can be considered a tax deduction from one's net income. (Tax Directorate General, accessed December 10 2011) Hence, the government provided a structure so that Muslims who paid zakat could deduct it from their taxes, e.g., Act No. 25 (2010) stipulated zakat payments to be tax deductible. (Akhmad Akbar Susamto, 2003: 107-118). But tax officials have been concerned that making zakat tax deductible will drastically reduce tax revenues. (I. Yani, accessed May 20), 2010).Some have even reported concern about the possibility of false claims, but there is a lack of studies 
to confirm this issue. Hence, an effective recordkeeping system for zakat payments is critical, and regulations that better facilitate BAZIS institutions will maximize the collection of zakat funds and their immediate redistributive economic impact that benefits the poor.

Because the success of LAZIS in raising zakat monies became public, in 2005, the government attempted to take over the LAZIS and to consider BAZIS the only zakat institution that would collect and distribute zakat. However, this caused some protest from LAZIS institutions because they believe that unrealized zakat payer potential had been significant, and the number of zakat institutions working with society had been too few to meet the needs of both the zakat payers and the entitled. LAZIS institutions have historically worked well in serving the poor, and LAZIS officers have proven to be far more effective in collecting and distributing zakat. Therefore, the government should not eliminate the roles of LAZIS institutions because they support some of the governmental duties that have not been fulfilled due to the government's limited budget to deal with poverty issues.

Some have suggested that supporting LAZIS is necessary for raising zakat monies to help the poor in Indonesia because the government is dependent on taxes. LAZIS institutions could play an important role to fill this gap because the zakat potential in Indonesia is tremendous because of the large population. (Dobias, 2002) Of the 246 million Indonesians, Muslims constitute $87 \%$, and $40 \%$ of these are wealthy enough to offer zakat. ( M.D. Doa, 2005). The combination of zakat with other voluntary gifts has the potential to generate $\mathrm{Rp}$ 19 trillion ( $\$ 1.9$ billion) yearly to be used to help the needy. In 2009, only Rp 1.2 trillion (\$120 million) was collected, (M.D. Doa, 2005) and in 2010, Rp 1.5 trillion (\$150 million) was collected, as well as Rp 1.8 trillion (\$180 million) in 2011. (Suara Merdeka September 12, 2012). This prediction included only zakat distributions at institutions, and there is a lack of data of zakat giving to individuals.

\section{Conclusions and Implications}

Zakat has survived within changing times and places since shari' $a$ was first decreed for Muslims in Mecca and Medina in the 7th century. The Islamic states had a great role in managing the mechanism of zakat. Within its long history, few detailed records have revealed how the Islamic states gave voice to the poor about zakat they received. The provision for zakat under shari' $a$ is similar to law about taxes in modern times. Although the Qur'an does not explain the explicit mechanism for poverty alleviation objectives, the deepest meaning of zakat rests in the Islamic states' structure and functions as wealth circulation among the communities. In the time of the Prophet Muhammad until the late Ottoman Empire, money from zakat was mixed with shadaqa (voluntary giving). In the second caliph era, Umar established the waqf system first in Islam, and it was further developed in the Ottoman Empire and in Indonesia.

To optimize the work of BAZIS and LAZIS, it is considered beneficial for both sides to collaborate in mutual respect and fair competitiveness. LAZIS have worked well in serving the poor. The government, with its authority, should not eliminate the roles of the private institutions. Apart from the existing polemics, both institutions should collaborate to eradicate poverty instead of competing for zakat funds. They should involve external auditors in assessing their funds. The results of audits should be published to educate society 
and to encourage people toward giving zakat. People will thereby know how the funds are collected and distributed to the poor, orphans, and other worthy recipients.

In managing zakat funds, LAZIS not only fill moment-to-moment needs in many of its programs, such as providing food for poor people, but they also have sustainable programs to empower economic advances for the poor, such as interest-free loans, training, scholarships, and education. BAZIS should learn from LAZIS which have sustainable programs to empower the poor through education and economic programs. In addition, LAZIS institutions cannot be considered as competitors with the government for zakat funds, but they should be considered as partners in poverty eradication.

Indonesian social work practice pays little attention to the need for increasing amounts of zakat and other voluntary gifts; it should advocate for best legislation that facilitates Muslims in fulfilling their religious obligations to the unfortunate. Acceptance of the present zakat institutions is increasing over time as the institutions become trustworthy intermediaries between donors and recipients. Therefore, Indonesian social work practice should become more involved in promoting zakat and voluntary giving because social work must advocate for the enhancement of living conditions of the poor and the destitute.

The appropriation of zakat funds during the era of Mamluk Egypt by zakat collectors, during the era of the Dutch colony by local rulers in Indonesia, and during the era of President Suharto's government shows the need for a greater role of social work practice, namely to advocate for institutional transparency, program delivery accountability, and bureaucracy reformation. To achieve this purpose, Indonesian social workers must collaborate with BAZIS or LAZIS to establish ethical conduct standards in order to protect the poor's rights to welfare equality. 


\section{Bibliografi}

Abdullah, Taufik. "Zakat Collection and Distribution in Indonesia." Ed. Mohammed Ariff. Islam and the Economic Development of Southeast Asia: The Islamic Voluntary Sector in Southeast Asia. Singapore: Institute of Southeast Asia Studies, 1991.

Abidin, Hamid. Reinterpretasi Pendayagunaan ZIS Menuju Effectivitas Pemanfaatan Zakat, Infaq, dan Shadaqah. Jakarta: Piramedia, 2004.

Adnan, Muhammad Akhyar and Barizah, Nur. "Accounting Treatment for Corporate Zakat: A Critical Review." International Journal of Islamic and Middle Eastern Finance and Management 2, no. 1 (2009): 32-45.

Al-Bukhari, Sahih. The Translation of the Meanings of Sahih Al-Bukhari. Riyad: al-Maktab al-Riyad al-Haditha, 1997.

Al-Falah Foundation. "Program.” http://www.ydsf.org/en (accessed September 2, 2010).

Ali, Muhammad Daud. Sistem Ekonomi Islam Zakat dan Waqf. Jakarta: University of Indonesia Press, 1998.

Al-Qardawi, Yusuf. Fiqh Zakat: A Comparative Study of the Rules, Regulations, and Philosophy of Zakat in the Light of the Qur'an and Sunnah. London: Dar Al-Taqwa, 1999.

Arjomand, Said Amir. 1989. "Philanthropy, the Law, and Public Policy in the Islamic World before the Modern Era." Eds. Stanley N. Katz and Edward L Queen II. Philanthropy, the Law, and Public Policy in the Islamic World before the Modern Era. Bloomington: Indiana University Press.

Bamualim, Chaedar S. "Islamic Philanthropy in Indonesia: Trends and Challenges toward Social Justice.” Jurnal Kultur 4, no. 1 (2009): 75-88.

Bashear, Suliman. "On the Origins and Development of the Meaning of Zakat in Early Islam." Arabica 40, no. 1 (1993): 84-113.

Benthall, Jonathan. "Financial Worship: The Quranic Injunction to Alms-giving." The Journal of the Royal Anthropological Institute 5, no. 1 (1999): 27-42.

Boland, B.J. The Struggle of Islam in Modern Indonesia, The Hague: Martinus Nijhoff, 1982.

CIA World Factbook. "People: Population, Religion." http://www.cia.gov/library/publica tions/the-world-factbook/geos/xx.html (accessed March 21, 2011).

Clark, Grace. "Pakistan's Zakat System: A Policy Model for Developing Countries as a Means of Redistributing Income to the Elderly Poor." Social Thought 20 no. 3 (2001): 47-75.

Dallal, Ahmad. 2004. "Islamic Institution of Waqf: A Historical Overview.” Ed. Stephen

P. Heyneman. Islam and Social Policy (Nashville: Vanderbilt University Press).

De Zayas, Farishta G. The Law and Institution of Zakat: The Islamic Social Welfare System. Kuala Lumpur: Islamic Book Trust, 2007.

Doa, M.D. Zakat under the State Management. Jakarta: Nuansa Madani, 2005.

Dobias, Robert. Investing in Ourselves: Giving and Fund Raising in Indonesia. Metro Manila: Public Interest Research and Advocacy Center, 2002. 
Dompet Dhuafa. "Zakat untuk Bangsaku." http://www.dompetdhuafa.org/home.php (accessed September 2, 2010).

Fauzia, Amelia. "Faith and the State: A History of Islamic Philanthropy in Indonesia" Unpublished Dissertation. The Asian Institute, The University of Melbourne, Australia, 2008.

Hasan, Muhammad Ali. Zakat dan Infaq: Salah Satu Solusi Mengatasi Problema Sosial di Indonesia. Jakarta: Putra Grafika, 2002.

Islamic Society of North America. Islam. http://www.isna.net/Islam/pages/Zakat-Al-Fitr-isWajib.aspx (accessed March 3, 2010).

Khalidi, Tarif. The Qur'an: A New Translation. New York: Penguin Classics, 2008.

Kodir, Faqihuddin Abdul. 2004. "Zakat dan Pemberdayaan Perempuan untuk Perubahan Sosial.” Ed. Hamid Abidin. Reinterpretasi Efektifitas Penggunaan Zakat, Infaq, dan Shadaqah. Jakarta: Piramedia.

Kompas. "Pengelolaan Zakat.” Http://www.kompas.com (accessed January 20, 2010).

Kozlowski, Gregory C. 1998. "Religious Authority, Reform, and Philanthropy in the Contemporary Muslim World." Eds. W.F. Ilchman, S.N. Katz and E.L. Queen II. Philanthropy in the World's Traditions. Bloomington: Indiana University Press.

Kuran, Timur. 2003. Islamic Redistribution through Zakat: Historical Record and Modern Realities. Eds. Michael Bonner, M. Ener and Amy Singer. Poverty and Charity in Middle Eastern Context. New York: State University of New York Press.

Latief, Hilman. "Islamic Aid and the Rise of Charitable Clinics in Indonesia." South East Asia Research 18 no. 3 (2010): 503-553.

Lessy, Zulkipli. “Zakat (Alms-giving) Management in Indonesia: Whose Job Should It Be?" La Riba Journal of Islamic Economy 3, no. 1 (2009): 155-175.

Lessy, Zulkipli. "Philanthropic Zakat for Empowering Indonesia's Poor through Maturing Social Work Research and Practice. Unpublished Paper. School of Social Work, Indiana University, Indianapolis, 2011.

Mas'udi, Masdar F. 1995. "Zakat: Konsep Harta yang Bersih.” Ed. Budhi MunawarRachman. Kontekstualisasi Doktrin Islam dalam Sejarah. Jakarta: Paramadina.

McChesney, Robert D. Waqf in Central Asia: Four Hundred Years in the History of a Muslim Shrine, 1480-1889. Princeton, NJ: Princeton University Press, 1991.

Profil RZI. "Rumah Zakat Indonesia." Http://www.rumahzakat.org (accessed May 1, 2009). Public Interest Research and Advocacy Center. Investing in Ourselves: Giving and Fund Raising in Indonesia. Manila: Asian Development Bank, 2005.

Sabiq, Sayyid. Fiqh Sunnah. Jakarta: Daar al-Fikr, 1992.

Salim, Arskal. "The Influential Legacy of Dutch Islamic Policy on the Formation of Zakat (Alms-giving) Law in Modern Indonesia.” Pacific Rim Law and Policy Journal 15, no. 3 (2006): 683-701.

Salim, Arskal. Challenging the Secular State: The Islamization of Law in Modern Indonesia. Honolulu: University of Hawai'i Press, 2008a.

Salim, Arskal. The Shift in Zakat Practice in Indonesia from Piety to an Islamic Sociopolitical-economic System. Chiang Mai: Silkworm Books, 2008b. 
Senturk, Omer Faruk. Islam in Practice: A Comprehensive Guide to Zakat Charity in Islam. Somerset, NJ: The Light, 2007.

Shaik, Abdool Aziz. 1980. "Concept of Zakah: A Survey of Qur'anic Texts and Their Explanations in Shariah and Contemporary Economics.” Ed. M. Raquibuz Zaman. Some Aspects of the Economics of Zakat. Indiana: American Trust Publications.

Singer, Amy. Charity in Islamic Society. Cambridge: Cambridge University Press, 2008.

Suara Merdeka. "2011, national zakat collected Rp 1.8 trillion," retrieved from http://www. suaramerdeka.com/v1/index.php/read/news/ (accessed September 12, 2012).

Susamto, Akhmad Akbar. "Zakat as Deductible for Taxable Income: A Macroeconomic Perspective.” Iqtisad Journal of Islamic Economics 4, no. 2 (2003): 107-118.

Tax Directorate General. "Decision Letter of Tax Directorate General: KEP-542/PJ. h/200." http://www.ortax.org (accessed December 10, 2011).

Vatikiotis, Michael. "Charity Begins at Home: Indonesian Social Foundations Play Major Economic Role.” Far Eastern Economic Review 150, no. 40 (1990): 62-63.

Visser, Hans. Islamic Finance Principles and Practice, Northampton, MA: Edward Elgar Publishing, 2009.

Wadjdy, Farid and Mursyid. Waqf dan Kesejahteraan Ummat: Filantropi Islam yang Hampir Terlupakan. Yogyakarta: Pustaka Pelajar, 2007.

Wheeler, Brannon. "Touching the Penis in Islamic Law." History of Religions 44, no. 2 (2004): 89-119.

Wilson, Rodney. "The Development of Islamic Economics: Theory and Practice.” Eds. S. Taji-Farouki and B.M. Sufi. Islamic Thought in the Twentieth Century. New York: St. Martin's Press, 2004.

Yani, I. “Tax Directorate General Denounced Zakat Could Deduct Taxes.” Kompas. http:// www1.kompas.com/Ditjen (accessed May 20, 2010). 